\title{
Muslim Sicily and the Beginnings of Medical Licensing in Europe
}

\author{
Leonard C Chiarelli, PhD \\ Salt Lake City, Utah
}

\begin{abstract}
One of the legacies of Arab tule in Sicily is in the area of medicine, its study. and practice. Those who study the history of medicine scem to agree the first regulations on the licensing of physicians and pharmacists in Europe can be traced to 1140, when the Norman king of Sicily, Roger II (1095-1154), established the requirement of physicians taking an examination before they could practice medicine. Later, the Hohenstauffen king of Sicily, Frederick $\Pi$ (11941250), went furher in his Constitutions of Melfi by Icgislating that for a physician to practice medicine or to heal, he first must be approved in a convened public examination by the master of the School of Salerno. Thus, with the adoption of this legislation, the procedures for the practice of medicinc in Europe began and soon spread to Spain and France. The origins of these regulations, however, seem to have their roots in the medical practices of the Arahs, who via North Africa, transferred them to Sicily. The period of Muslim rule on the island had also introduced schools teacbing the art of medicine and established hospitals. The Norman conquest, together with the licensing of physicians, the schooling, cxanining, and practicing of the medical arts, brought these traditions to medieval Europe, where they became the foundation of Western medical customary practice.
\end{abstract}

Key words: Medieval medicine, medicval Sicily, Muslim Sicily, nedical licensing.

$\mathcal{O}$ ne of the legacies of the period of Arab rule in Sicily is in the area of modicine, its study, and practice. Scholars in the history of medicinc appear to agree that the first regulations governing the practice of physicians in Europe dates to 1140. when the Norman king of Sicily, Roger II (1095-1154), established in his laws, the "Assizes," the requirement that physicians must be exarn-

From the Marriol Library

Universily of Utah

Salt Lake City, Utah

Reprint Requests: Leonard ('Chiarelli, PhD

Marriot Library

University of Utah

Salt Lake City, UT 81112 ined before they could practice medicine.' The relevant text reads: "Whoever in the future desires 10 become a physician slould present hiniself to our oflicials and judges for an examination according to their judgment."2 Later, the Hohenstauffen King of Sicily. Frederick II (1194-1250), went further in his Consticutions of Melfi Riber Augustalis) by legislating that "in the future no one may dare otherwise to practice or to heal, pretending the title of physician, unless lic has first been approved in a convened public examination by the Masters of Salerno," and that "testimonial letters concerning his trustworthiness and sufficient knowledge" should be presented before the examining body before he may "obtain the license for healing from us." Those making medicincs were obliged to take an oath to "make them faithfully." The adoption of this legislation in 1231 appears to have sel the procedures for the praclice of medicine ist Europe, and soon they are found in the other parts or 
Italy, then in Spain and France in the following century. ${ }^{3}$ The origins of these regulations, or at least their inspiration, seem to have their roots in the medical practices of the Arabs ${ }^{4}$ who, via North Africa, transferred them to Sicily.

The possible influence of Islanic modical practices upon modieval Europe has hardly been studied, although it is known that Arabic medical lexts lad a profound impact on scientific learning of Europe. Гл ar article addressing ithe antecedents of the Norman legislation on medical exanunations and licensing. the American nedievalist James $M$ Powcll states that the Latin Norman texts, and the practices themselves, evidence Byzantine influence. He goes on to mention, however, that the Greek text upon which lis conclusion is based is not clear and that there is no definitive picture of the medical profession practiced in Byzantiun. He even declares that the "precedents" for the Norman laws on medical practice are largcly unknown." Nowhere in the article does he mention that these laws, or their inspiration, may have had a connection with the Arabs who rulcd the island for 200 years prior to the arrival of the Nonnans. and whlose institutions were still in praclice when King Roger II promulgated these laws.

The licensing of medical practitioners appeirs to lave begun in Baglidad in 931, when a man died due 10 a physician's error. The Abbasid caliph, al-Muqladir (908932), alarned by this death, decreed that the Inspector of Markets. "Mulurasib" or "Sāhib al-Sīq" should not allow anyone to practice medicine unless lie was licensed by the caliph's chief physician. ${ }^{7} \mathrm{He}$ first had to examine the quali. fications of the prospective practitioner before issuing a "'Ijäzah," a certificate or license. ${ }^{8}$ The 'ijäzah was usually' a letter issued by a student's tcacher attesting that he leid successfully completed a set course of sludy under his supervision, and that he was certifying that he was competent to teach the said subject."

Soon this procedure spread ihrougliour the Muslim East and West, but wills some variations. For example, it is know'n that sludents who received their education and training in a hospital would reccive their license from the licad practicing physician. ${ }^{10}$ Then, in order 10 practice, the medical practitioner was obliged to be examined by the nulutasib. who tiercancr administered to him the Hippocratic Oath and issued a permit or license." І п many cases, the prospeclive plyysician would first be examined by the chief pliysician who was appointed by the government 10 be "head of his cran $^{\prime \prime 2}$ and subjoce to the control of the muhtasib, ${ }^{13}$ an appointed government official who was under the authority of the "Qādi.". a municipal judge, and whose major function was to be guardian of public morals and the regulaling of all trades in the market. His duties embraced the various aspects of public life, from keeping the walkways and batls clean, to protecting flie public from frnud. As such, he was claarged with licensing physicians, phannacists, oculists, and blood-letters, etc."1 as wcll as miaking cenain that the weiglus and measures of the inercliants in the inarkel were accurale. Handbooks were conpiled (liat detailed his responsibilitics and the procedures he was to follow in order to allow merchants and health practitioners to carry on their business.

The office of the multasib seems to date back to the 9th century's but soon became widespread, extending within a century to North Africa, Spain, and Sicily. ${ }^{16}$ At times, in addition to the "ijazzah, the aspiring physician had to present a certificate of good conduct issued by the "Sahib al-shurtah," the chief of police."

The study of medicine among the Arabs began soon after the 9 th century, when the learning center. the House of Wisdom (Bayt w-Hikmalı), started Iranslating into Arabic the ancient Coptic. Greck. Sanskrit, Nabatacn, and Syriac medical works. ${ }^{18}$ In a shon period of time. the study of these ancient texts spread to the Muslim West, where under the Aghlabid dynasty in Ifrigyah (Tunisia) a House of Wisdom, modcled after the one in Baghdad, was established. ${ }^{19}$

The Agllabids launcled their contuest of Sicily in 827. and. with the occupation of the whole island by $902, \mathrm{re}-$ mained under Muslim rule until the Norman conquest in 1086. However, the Arab element in the government and its buseaucracy, as well as its culture, continued in much of Sicily for another 150 years. The Tunisian scholar Hasan Husni abdul Wahliab stated Ulat afler llie invasion of Sicily. the Aghlabid "Amirs" (princes) utilized the Sicilian monks by bringing them to Qayrawān in order to have them translate the classics into Arabic. He also speculated that these monks were charged will doing llic same on the island. ${ }^{20}$

The Aglılabids also cslablished medical learning circles at Raqqādah and Qayrawãn, where by the llth century, Ifriqyal became a cculer for the leaching of medicine. Eminent physicians from Egypt and Baghdad were asked to sclle in Qayrawān in order 10 leacls and praclice medicine amoug the menbers of the amir's courn. Sucli well known figures as "Islıạ ibn 'Unrān (fl. Ytl century). 'Islyàq ibn

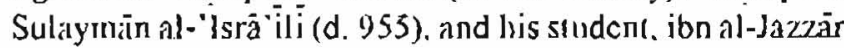
(d. 980), laught and wrole renowned works on disease and the pracsice of medicine. The writings produced there made Qayrawàn a center for medical learning. which came to influence the whole of Norls Africa, including Spain and Sicily." Along wish schools taching medicine. they establislied hospitals, known there by the Berber word "dimnah," which made their appearance around 831 in Qayrawān but soon spread lluroughoul the larger cities of Ifrigyah. ${ }^{27}$

Surviving letters of Jewish merchants of thic period. known collectively as the Geniza documents, clearly demonsirale ilat Qayrawan was an acsive medical learning center for Jews and Muslims alike. ${ }^{33}$

Tlse study and praclice of medicine in Norll Africa surcly had an impact in Sicily. Although specific documents related to medical learnitig and praclice on the island have so far eluded uts, lhere is some evidence to show (hat Sicily had been part of the medical regine of Qayrawäl. Even (hougl) medical leaming was concentrated in Ifrgiyah. Sicily nol only lead its medical practitioners but also personages who leclured in medicine. The renowned religious scholar. 'Abu Sa 'id Luquān ibn Yüsuf al-Glassāni (d. 931) 
of Qayrawān spent 14 years in Sicily teaching religious law and medicine. ${ }^{24} \mathrm{~A}$ native Sicilian, 'A $\overline{\mathrm{i}}$ ibn al-Hasan ibn al-Tubi (nl. 1 I h century) traveled abroad and then returned home as a learned physician who followed and taught the medical teachings of the famous 9th century Baghdad physician and teacher Yühannā ibn Mäsawaih (d. 857). ${ }^{20}$

Another native of the island. "Ali ibn lbrahim ibn "Ali (d. 1137), called "Son of the Teacher", taught mcdicine and was known as an eninent grammarian and calligrapher. ${ }^{26}$ Some of the government officials sent to the island from Qayrawān were skilled in medicine. For example. Muhammad ibn 'Ibrāhìm ibn 'Abi Säbiḥ (d. 944), who was sent as the chicf judge or "Qüd" of the island, was in addition to an expert in religious law, a well-known physician. ${ }^{n}$

The teaching of basic medicine seems to have had a place in the cducational system on the island and there is no doubt that the ancient Greck works on medicine, mechanics, and philosoplyy. which were to be found in the libraries of Palerno and Syracuse, were utilized. It secms likely that the ancient Greco-Roman library in Syracuse continued to be active throughout the period of Arab rule since we read in a letter wriken by the Norman official and arclideacon of Catania. Henricus Aristippus (n. 1150). 1hat "you have in Sicily the Syracusan and Greek library." An indication of the knowledge and availability of the Greck works is indicated in the report that in 951, the Umayyad caliph of Spain, 'Abd al-Rahnnān IlI (912-96I), soughl thc assistance of the Sicilian physician 'Abü 'Abd Allôn (n. 10th century) to help tunnslate the "Materia Afedica" of Dioscorides. He was sought oul because of his knowledgc of the Greek language and his mastery or nuedicinal plants. ${ }^{2}$ Another Sicilian, whose name and work have been losi, wrote a book on materia medica and prescriptions entil led Kitäb al-Sigilli (The Book of the Sicilian), which covers many areas of pharınacology. ${ }^{30}$

It is even possible that there werc female medical practitioners in Muslim Sicily. There is no direct informalion concerning their practice, but it is well known that fenale physicians thrived in the lslamic world, ${ }^{3}$ and it is reported that in the 141h century Sicily had, along with Florence, the largest number of fermale medical praclitioners in all of Italy. "?

In regards to the establishment of hospitals, it appears Unat the hospital known as San Giovanni dei Lcbbrosi located outside Palenno and attributed to Norman construction, is of older origin and was originally the Arab castle of Yahya. In fact, Sicilian historian Michele Anari states that there is no document that proves that it was built by the Normans. ${ }^{3}$ The Spanish Muslim traveler ibn Jubayer sin this hospital in 1185 and noled that it was consuructed on the model of the Muslim hospitals he saw in Acre and Tyre., As far as the examining and licensing of physicians, it seems that Sicily lad the same procedurcs as thosc found in North Africa. The office of mulutasib wenl under various titles at different times and places. Originally, the oflice went under the uite of șithib al-süq and remained under lhat name in some parts of the Muslim world. "Muhtasib" was a tille predominately found in the Arab East, while in North Africa and Spain, we often find the tille "Șāhịb al-sūq," "Àmil al-sūq," or even "Șāhib al-shurtah" (chief of police)." It ofien occurred that the position of muhtasib and shurtah were joincd, which may have been at the discretion of the appointing qaddi. ${ }^{36}$ The inspector of markets, then, could be called "muhtasib," "ṣāhị al-sūq," or "șāhib al-shurah."

Sicilian documents indicale that the office of "sahib alsūq," master of the market, was still in use in Sicily around 1145 , i.e., during the period that Roger [l's laws were made. ${ }^{37}$ Later, documents from the period of Angevin rule (12641283) show that in 1282, the office and the title continued under the Latin form magistrum mercii. ${ }^{18}$ During the same period, another document also used the title "magistris Surte mercii," i.e., "chief of police of the narkets." 39

Historical documents indicate that during the period of Muslim rule, Sicily followed the same administrative framework as other Muslim regions, with the office of chief physician and muhtasib active in exantining, certifying, licensing, and oversceing medical practitioners. The procedure appears 10 be that the medical student received a license or diploma from his mentor on completion of his studies. Then. if he wished to practice medicine, he was examined first by a government-appointed chief physician whose position was similar to a master of a trade guild. Thereafter, if approved. he would reccive a license to practice from a judicial official, the nuheasib or șăhib al-sūq.

The laws of Roger il appear to llave adopted and codified ilse process, and in doing so, incorporated some of the laws of the Muslim community." There is ample evidence to show that Islamic law continued to be used on the island up through the 121h century." Tlue Assizes promulgated by Roger II were meanl to fix the obligations and competence of the royal officials, ${ }^{12}$ of which the office of mutitasib was probably included. At the time the laws were drawn, Arab oflicials held many royal positions of importance."." and the king sought via the new laws 10 unify the administrative sysicm so that it wonld embrace the traditions of Latin and Greck faly with those of Muslin Sicily. ${ }^{41}$ As part of the king's administrative reorganization, he codified the obligations of the royal officials, thereby placing the office of muhtasib, and probably "chief physician" as examincr, under a centralized royal administrative system.

Il appears that hater Frederick II elaborated on Roger II's Icgislation in his Constitutions of M/elfi by placing the responsibility of cxanining and licensing of niedical practitioners upon a board of medical examiners at the medical school at Salcrmo thus, not only codifying, but institutionaliziug, the proccdures for cxamining and licensing of physicians.

A delailed study, however, of the Liber Augustalis and lic Assizes is needed to deduce if their conlenls concerning the provisions on health were influenced by the Mustim community. on the island and especially if the literature of the office of nulylasib had any impact. ${ }^{\text {as }}$ The formalized 
regulations of Frederick II appear to have had an impact on the European mainland where the study and practice of medicine was beginning to hourish in the great medical schools of France. Italy, and Spain.

\section{Refcrences}

1. Conrad LI: The ivestern medical Iradition, $800 \mathrm{BC} 10$ 1800 AD. Cambridge: Cambridge Universily Press, 1995:162.

2. Powell JM, cditor and Iranslator: The Liber Augustalis. Syracuse: Syracuse University Press. 1971:131.

3. Shatzmiller J: Jews, medicine, and medicval sociery. Berkeley: Univerisity of California Press. 1994:14-5.

4. McVaugh MR: Medicine before the plague. Cambridge: Cambridge University Press, 1993:69,78.

5. Reference 2: 63-4.

6. Takayama H: The administration of the Nornan Kingdom of Sicily. Leiden: EJ Brill, 1993:165.

7. Makdisi G: The rise of humanism in classical Islam and the Cliristian west. Edinburgh: Edinburgh University Press, 1990:249.

8. Ibn Rựwān A: Medieval Islanic medicine. Dols MW, editor and translator. Berkeley: University of California Press, 1984:32.

9. Stanton CM: Higher learning in Islam. Savage. Maryland: Rowman \& Littleticld Publishers, Inc.. 1990:125, 168. 10. Meyerhof M: Science and Medicine. In: A nold $T$. editor. The legacy of Islam. Oxford: Oxford University Press. 1943:336.

11. 'Abd al-Raḥmān ibu Nașr al-Shayzari: Kitāb Nị̣nyal al-rutbah fí talab al-hisbals. Al-Bay al-'Arini S, editor. Cairo: Association of Authorship. Translation and Publicalions Press. 1946:97-9.

12. Ibn al-'Ukhuwwalı: Al-Ma“ālinı al-Qubrā fí A ḥkām alHisbah. Levy R, editor and translator. London: Luzac \& Co. 1938:57,166.

13. Sa id al-Andalusi: Science in the nedieval world: "Book of the calcgories of nations." Salcm SI, Kunar A. cditors and transtators. Austin: Universily of Texas Press, 1991:73.

14. Buckley RP: The Muthiasib. Arabica 1992:39:90.

15. Haunanieh SK: Origins of pharmacy and therapy in the Near East. Tokyo: Naito Foundation, 1973:47.

16. Hamarneh SK: Origin and function of the hisbah systcm in Islam and its impact on the health professions. Health Sciences in Early Islam, 2 vols. Anees MA, editor. Blanco. Texas: Noor Healih Found and Zahra Publications. 1983:1:114.

17. Goitein SD: Mediterranean Socicty, 6 vols. Berkelcy: University of California Press, 1967-1990;2:250.

18. Hamamch SK: Medical cducation and praclice in Islam. In: Health scicnces in early Islam, 2 vols. Anees MA. cditor. Blanco, Texas: Noor Healfl Found and Zalhra Publications, 1983:1:127.

19. 'Abdut Wahhāb HH: Waragat, 3 vols. Tunis: al-Manār. J965-1972:1:196.

20. Reference 19: 200-3.
21. Jacquart D. Miclieau F: La medecine arabe et l'occident medieval. Paris: Maisonneuve et Larose, 1990:111-3.

22. Refcrence 19: 274-94.

23. Goiten: Mediterranan Sociely, 1967-1990:2:203-4.24060.521 .

24. 'Jyād ibn Müsā: Tartib al-madārik wa-Laqríb al-masâlik li-nia 'rifat a'lam nadhhab Mălik, 4 vols. Beirut: Maktabat al-Hayāh, 1967-68:3:312.

25. lbu al-Qatta A: al-Durrāt al-khatirah. Beirut: DāralGharb al-Istāmi, 1995:172-3.

26. 'Ali ibn Yüsuf al-Qinti: Inbah al-rugah 'ala anbah alnuhall. Ibrahion $M$, editor. 4 vols. Cairo: Dār al-kulub wal-watlıà'iq ał-qawniyygh, 1950-1973:3:220-1.

27. Reference 24:357.

28. Grant E: Henricus Aristippus, William of Moerbekc and two alleged medieval translations of hero's pneurnatica. Speculum 1971;46:656.

29. Ibr 'Abi 'Ușaybi'ah. 'Uyưn al-'Anbā' fí cabaqāt al'autibba'. 3 vols in 1. Bcinu: Dār al-Fikr. 1956:3:76-7.

30. Grifini E: Nuovi testi arabo-siculi. In: Centenario delia Nascita di Michele Amari, 2 vols. Palermo: Virzi. $1910 ; 1: 445$.

31. Reference 1: 129.

32. Garciá-Ballestcr L, editor. Praaclical medicine form Salerno to the black death. Cambridge: Cambridge Universily Press. 1994:17.

33. Amari M: Storia dei Musul mani di Sicilia. 2nd edition. 6 vols. Calania: R Prampolini, 1933-39;3:8+5.

34. Ibn Jubir M: The (ravels of ibn Jubir. Broadhurst RJC, editor and translator. London: Jonalhan Cape, 1952:3407.

35. Chalmeta P: El "scnor del $\angle 0 c 0$ " en espana: edades media y moderna, contribucion al estudio de la historia del mercado. Madrid: Instituto Espano-Arabe de Culıura. 1)73:247,403.

36. Encyclopacdia of Islam, 2 nd ed.. s.v. Cahen C. Talbi M. "Hisba."

37. Cusa S: I Diplomi Greci ed Arabi di Sicilia. 2 vols. Palermo: Lao. 1868:2:577.

38. Mazzarese FE: De Rebus Regni Siciliae (9 setlembre 1282-26 agosto 1283), 2 vols. Palermo: Societa Siciliana per la Storia Patria, 1982:2:223.

39. Mazzarese FE: De Rebus Regni Siciliae, 1982;2:191. 40. Van Cleve TC: The emperor Frederick II of Hohenstaufen. Oxford: Clarendon Press, 1972:238.

41. Menager LR: La Legislation sud-italienne sous la Domination normande. In: I normanni e loro Espansione in Europa nell'Alto medioevo. Spole1o: Centro Itallano di Studj sull'Alto Medioevo, 1969:445.

42. Taknyama $\mathrm{H}$ : The financial and administrative organization of the Norman kingdom of Sicily. Viator $1985 ; 16: 148$.

43. Reference 42: 149.

44. Reference 42: 163.

45. 'Abd âl-Rahmmàn ibu Naṣr al-Shayzari: Kitāb Niḥāyat al-Rulbah fí (alab al-Hisbah. 1946:97-8. 